\title{
Pedogenic calcrete records in southern Transdanubia, Hungary: A brief review with paleoenvironmental and paleogeographic implications
}

\author{
Andrea Varga*, Béla Raucsik \\ Department of Mineralogy, Geochemistry and Petrology, University of Szeged, Egyetem utca 2-6, \\ H-6722 Szeged, Hungary
}

\begin{abstract}
In the Hungarian part of the Tisia Block, four occurrences of rhizolith-bearing pedogenic calcrete have been published, three of which are located in southern Transdanubia. Nodular calcrete with beta fabrics was documented from the lower Permian (Cisuralian) continental Korpád Sandstone Formation where the subaerial exposure section was developed on a strongly altered, volcanic shard-rich siliciclastic substrate. Additionally, two locations with Microcodium-bearing calcrete developed on a lower Jurassic carbonate substrate were published in the last few years. The scope of this study is to briefly summarize pedogenic calcrete records known from the Permian to the Cenozoic of southern Transdanubia (Tisia Block, Hungary), and to highlight their regional paleoenvironmental and paleogeographic importance.
\end{abstract}

Key words: calcrete, beta fabrics, subaerial exposure, Permian, Eocene, Hungary

\section{Introduction}

Calcrete is a near-surface, terrestrial accumulation of predominantly calcium carbonate (Wright and Tucker 1991; Alonso-Zarza et al. 1998; Alonso-Zarza 2003). Calcretes which were formed only when evaporation exceeded precipitation, i.e. when the climate was at least seasonally arid, are generally considered as reliable paleoenvironmental and paleoclimatic indicators (Wright and Tucker 1991; Alonso-Zarza 2003; Alonso-Zarza and Wright 2010; Brasier 2011). According to the descriptive morphological terminology of Wright (1990), at the simplest level two end-member microfabric types occur in calcretes. Alpha calcretes (e.g., groundwater calcrete) consist of micritic to microsparitic ground-

* Corresponding author; E-mail: raucsikvarga@geo.u-szeged.hu

Received: August 8, 2013; accepted: May 23, 2014 
masses, typically with such features as crystallaria, floating skeleton grains, large euhedral crystals, crystal size mottling and displacive growth features. On the other hand, beta calcretes (e.g., pedogenic calcrete) exhibit microfabrics dominated by biogenic features such as rhizoliths (organo-sedimentary structures produced by roots; Klappa 1980), microbial tubes, alveolar textures, and Microcodium.

The genus Microcodium was originally created by Glück (1912) for aggregates of unusually-shaped calcite crystals in Miocene marine deposits, and it was placed in the Codiaceae of the Chlorophyta. Two kinds of Microcodium were defined by Esteban (1972): 'Microcodium a' refers to typical Microcodium, consisting of prismatic calcite crystals; whereas 'Microcodium b' was defined by its smaller grain size and subquadrangular sections of its prisms (atypical Microcodium). Based on a large number of reports, the original interpretation of Microcodium as siphonaceous alga or any other phototrophic microorganism has been rejected; however, the process of Microcodium formation still remains unsolved (Klappa 1978; Alonso-Zarza et al. 1998; Košir 2004; Kabanov et al. 2008). Microcodium was interpreted as a calcification product of a mycorrhizae-cortical root cell association by Klappa (1978). Alonso-Zarza et al. (1998) suggested that 'Microcodium b' formed through calcification of root cells. Similarly, Košir (2004) stated that morphology and structure of the typical Microcodium aggregates indicate that they formed through biologically-controlled precipitation of calcium carbonate within the root cortical cells. On the other hand, Kabanov et al. (2008) proposed a non-rhizogenic, biologically-induced origin for typical Microcodium ('type a') formation. According to these authors, it may be produced by actinobacterial or fungal substrate mycelia, probably in association with other bacteria capable of consuming metabolites of the mycelial organism. Therefore, the typical Microcodium is a biologically-induced mineralization driven by a saprotrophic microorganism or a microbial association decomposing dead terrestrial organic matter (rootlets and earlier generations of fungi, humified organic matter) (Kabanov et al. 2008).

Kabanov et al. (2008) provided an extensive review of the available literature for Paleozoic and Cretaceous-Cenozoic Microcodium occurrences. Unfortunately, however, there was no mention of Hungarian Microcodium records in that article. Among the paleosol sections in Hungary, calcretes from the Triassic cyclic peritidal-lagoonal platform carbonate succession and from the Pleistocene lacustrine setting of the Gerecse Hills, as well as Quaternary paleosol at the pediment of the Mátra Hills have received special attention (Bakacsi 1993; Bakacsi et al. 1994; Mindszenty and Deák 1999; Bajnóczi et al. 2006). Microcodium-bearing calcretes, however, have not been investigated in detail. On the other hand, pedogenic calcrete reports in the Hungarian part of the Tisia Block published in English are rare (Lelkes 1994; Varga et al. 2002a, 2002b, 2012); some papers are intended to reach only a Hungarian readership (Varga 2000, 2002, 2009, 2011; Varga et al. 2002c). The scope of this study is to summarize pedogenic calcrete re- 
cords known from the Permian to the Cenozoic of southern Transdanubia, Hungary, and to highlight their regional paleoenvironmental and paleogeographic importance.

Moreover, as Microcodium can be seen as a natural product of actinobacterial or fungal activity, corresponding to the nano- to microscale interaction between decomposing organic matter and a microbial association (Kabanov et al. 2008), this topic can trigger the multidisciplinary attention of researchers interested in the study of interactions of artificial nanostructures and biological systems.

\section{Pedogenic calcrete records in southern Transdanubia, Hungary}

In the central Carpathian-Pannonian area, the Mid-Hungarian Lineament, a key element in the tectonics of the Intra-Carpathian area, subdivides the pre-Ter-

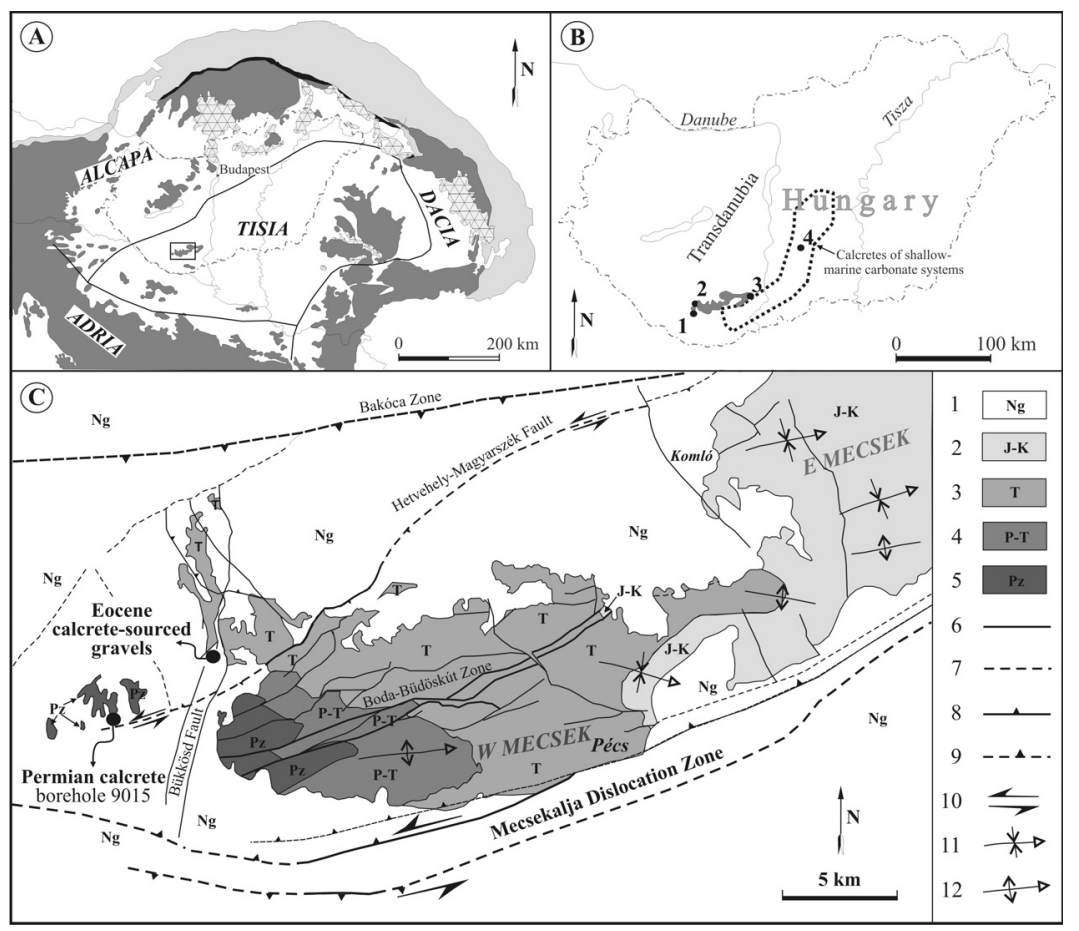

Fig. 1

A) Major tectonic units of the Carpathian-Pannonian area after Csontos et al. (1992, 2002). B) Location map of the pedogenic calcretes from the Hungarian part of the Tisia Block. 1 = Permian calcrete (Varga et al. 2012);2= Eocene calcrete-sourced clasts (Varga et al. 2002b); 3 = calcrete developed on Sinemurian substrate (Varga 2011); 4 = calcrete developed on Miocene (Sarmatian) substrate (Lelkes, 1994). C) Structural framework and generalized geologic map of the Western Mecsek Mts (Konrád and Sebe 2010). $1=$ Neogene; 2 = Jurassic and Cretaceous; 3 = Triassic; 4 = Upper Permian - Lower Triassic; $5=$ Paleozoic in general; $6=$ observed fault; $7=$ supposed fault; $8=$ observed reverse fault; $9=$ supposed reverse fault; $10=$ strike-slip fault; $11=$ syncline; $12=$ anticline 
tiary basement into two parts (Fig. 1A): the Alcapa (Alpine-West Carpathian-Pannonian) Block to the north and the Tisia (Tisza-Dacia unit or Tisza Mega-unit) Block to the south (Csontos and Nagymarosy 1998; Csontos et al. 1992, 2002). In the Hungarian part of the Tisia Block, four occurrences of pedogenic calcrete with in situ Microcodium or poorly-preserved Microcodiumlike structures have been published (Fig. 1B), three of them are located in southern Transdanubia.

\section{Paleozoic (Permian) occurrence}

In southern Transdanubia (Fig. 1C), Permian siliciclastic and volcaniclastic rocks were deposited in continental strike-slip and rift-related basins, belonging to the internal part of the Variscan orogenic domain (Barabás and Barabásné Stuhl 1998; Vozárová et al. 2009). Among these units, the fine-grained siliciclastic deposits of the Cisuralian Korpád Sandstone Formation are distinctive in terms of the presence of nodular calcretes with rhizocretions (Varga 2009; Varga et al. 2012).

The alluvial Korpád Formation occurs in the subsurface in southern Transdanubia and ranges up to $700 \mathrm{~m}$ in thickness, consisting of polymictic conglomerate, breccia, sandstone, and mudstone (Fazekas 1987; Barabás and Barabásné Stuhl 1998). This formation contains a sparse Early Permian macroflora (e.g., Pecopteris, Voltzites) and a lowermost Permian microflora composed of the Potonieisporites and Vittatina assemblage (Barabás and Barabásné Stuhl 1998). Calcretes and calcareous paleosol were not recognized previously in this unit; however, a large amount of individual dolomite concretions and concretionary aggregates, together with animal burrows, were described by Jámbor (1964) from the red siltstone samples (drill core 9015, near the village of Dinnyeberki, Mecsek Mts; Fig. 1C). Varga (2009) and Varga et al. (2012) reported that these carbonate concretions are, at least partially, of rhizogenic origin, representing nodular horizons of calcrete sections.

The studied subaerial exposure section developed on a strongly altered, volcanic shard-rich siliciclastic substrate where calcium could be derived from the hydrolysis of volcanic glass and plagioclase feldspar. The calcrete microfabric is characterized by the presence of micritic mottles, root traces (e.g., rhizocretions and smaller root casts; Fig. 2), and associated biogenic structures such as fecal peloids (rounded micrite pellets resulting from invertebrate defecation in the soil) and relic structures of in-situ Microcodium-like aggregates (in the sense of Klappa 1980 and Kabanov et al. 2008). Unfortunately, Microcodium appears as partly to totally recrystallized calcite grains, so no primary morphology could not be identified. The rhizocretions are complex tubular structures up to $1 \mathrm{~cm}$ in diameter, with a wall structure of irregular micritic laminae, which form roughly concentric layers around the central hollow filled by drusy calcite spar cement (Fig. 2B). 

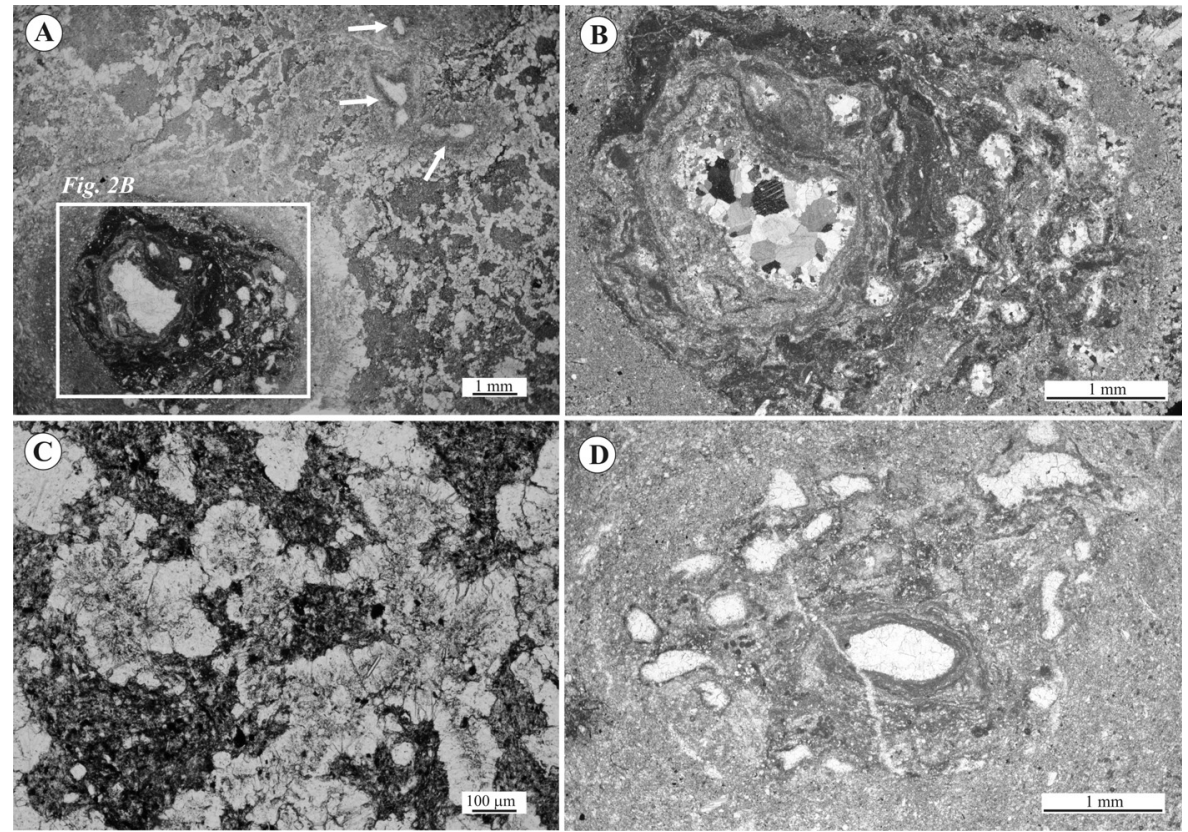

Fig. 2

Photomicrographs of petrographic thin sections of the Permian calcrete (A-C: sample 15.22.1; D: sample 15.22.2). A-B) Rhizocretion with complex tubular structure. Smaller second-order rhizocretions and root casts are obvious around the well developed central rhizocretion, suggesting vertical root systems with taproot and laterals (A: plane-polarized light; B: crossed Nicols). Smaller root casts are indicated by arrows. C) Strongly recrystallized Microcodium-like calcite aggregates with relics of dark, finely-dispersed inclusions in close vicinity to rhizoliths. Plane-polarized light. D) In surroundings of the second order rhizocretions small pellets are present. Plane-polarized light

In the pedogenic micritic laminae of rhizocretions, carbonate is replaced by tiny authigenic quartz, showing clear evidence for localized silicification (Fig. 3).

\section{Eocene Microcodium-corroding Jurassic (Pliensbachian) substrate}

Eocene calcrete-sourced pebbles were found in a lower-middle Miocene conglomerate sequence (Szászvár Formation) in the western part of the Mecsek Mts (Fig. 1C). Based on evidence from spore and pollen remains (Varga 2000; Varga et al. 2002a, 2002b, 2002c), local geology (Wéber 1982, 1985) and an ancient analogue (Gierlowski-Kordesch et al. 1991), the reworked calcrete seems to be related to the continental sequence of the Middle Eocene - Early Oligocene(?) Szentlőrinc Formation. Rocks of this unit are not exposed in Hungary; they were penetrated in significant thickness by boreholes in southern Transdanubia (Wéber 1982, 1985; Varga et al. 2004). 

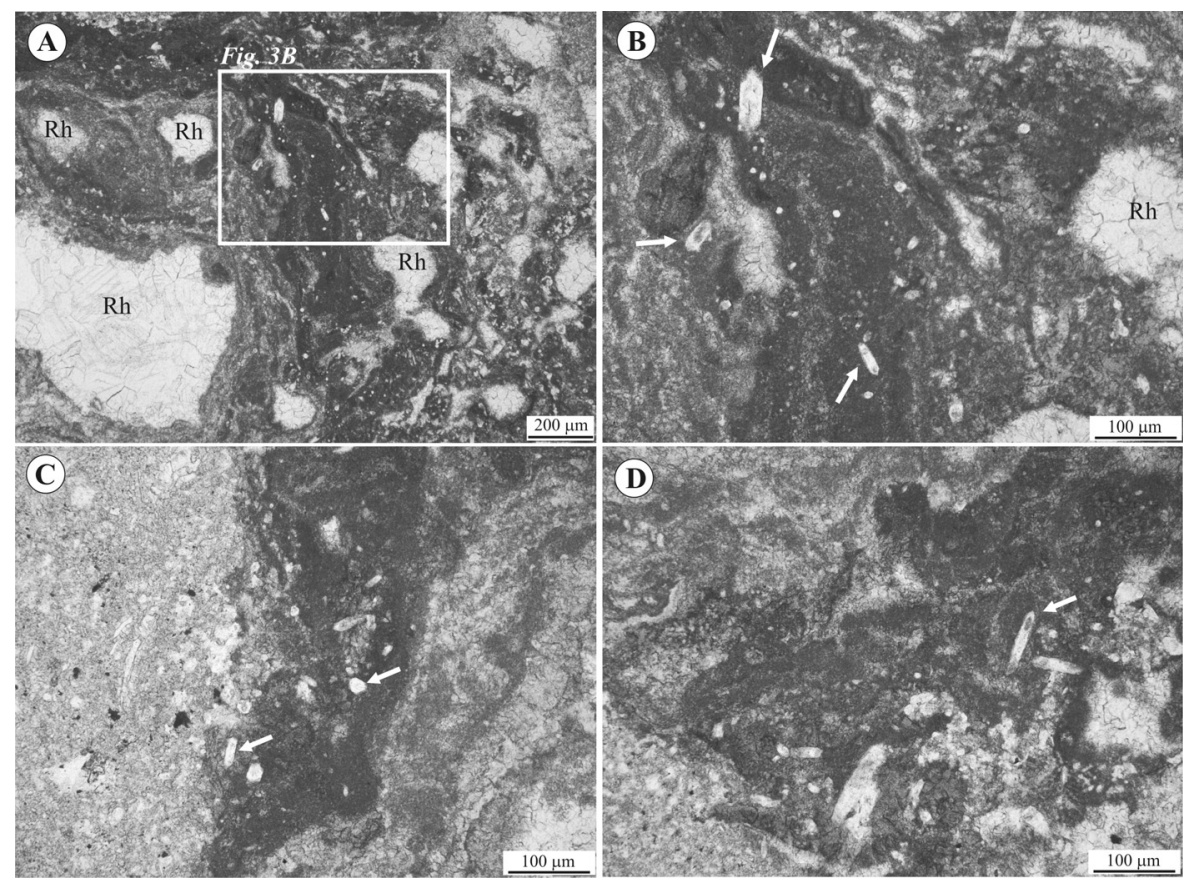

Fig. 3

Photomicrographs of petrographic thin sections of the Permian calcrete (sample 15.22.1). A-D) In the pedogenic micritic laminae of rhizocretions $(\mathrm{Rh})$, carbonate is replaced by tiny authigenic quartz with euhedral crystal terminations (arrows). Plane-polarized light

The depositional environment of the Szentlorinc Formation is interpreted as an alluvial system containing a carbonate-clastic alluvial plain (floodplain environment), locally with brown coal seams (Wéber 1982, 1985; Varga et al. 2002a, 2004). The provenance area surrounding the basin comprised Paleozoic (e.g., metamorphic and acidic volcanic fragments, fine-grained sandstone) and Mesozoic (e.g., Triassic limestone and dolomite, Jurassic limestone and marl clasts, Cretaceous limestone clasts derived from the Mecsek-Villány zone, and altered basic volcanics) rocks supplying the clastics (Varga 2002; Varga et al. 2002a, 2004). The basement is partially constituted by a supposed karst system correlated with the Jurassic Szársomlyó Limestone of the Villány area, delivering bedload and dissolved carbonates into the sedimentary basin (Varga et al. 2004).

The beige-colored reworked calcrete consisting of sand and gravel-sized clasts coated by laminated micrite was able to develop on a carbonate rock substrate associated with an alluvial fan system containing fragments of Mecsek-type Lower Jurassic rocks (Varga 2000; Varga et al. 2002c). Calcrete microfabrics reveal coated grains, peloids, rhizoliths, alveolar textures, and well-preserved in-situ Microcodium aggregates (Fig. 4). The root structures are mostly represented by root casts and rhizocretions but root petrifaction also occurs. Some root casts are 

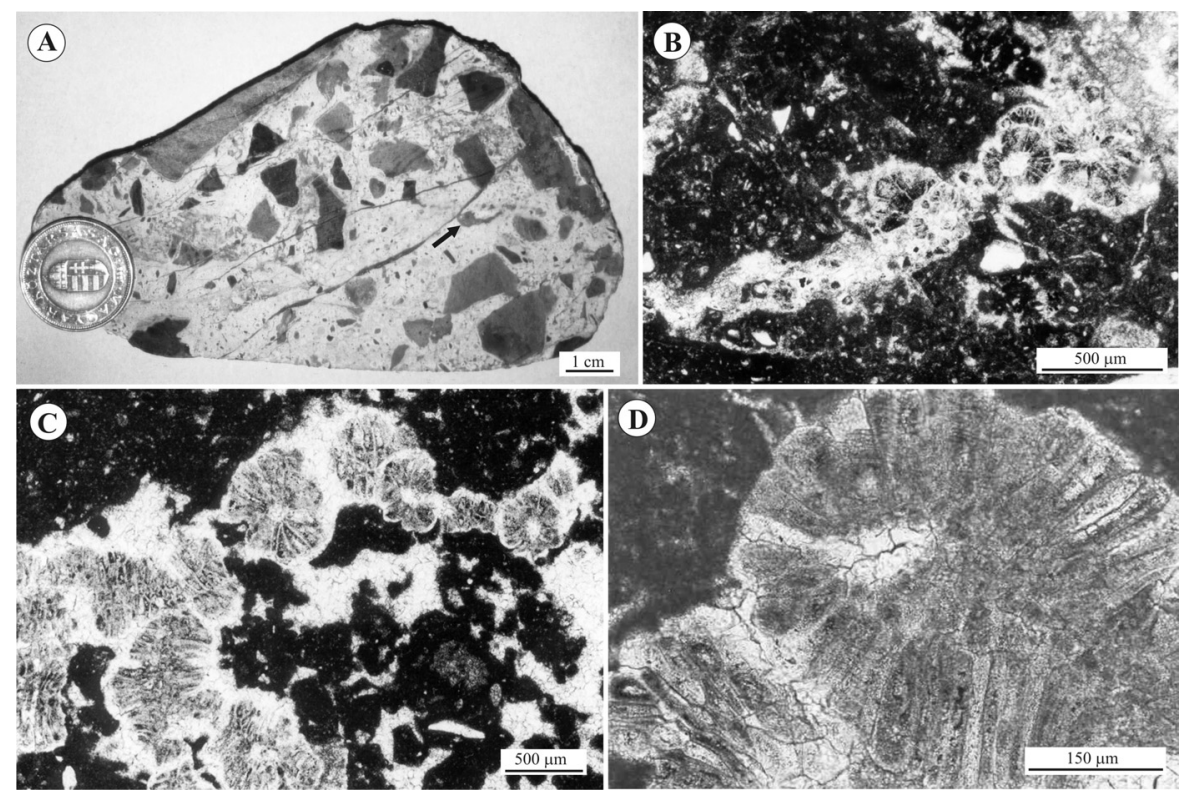

Fig. 4

Eocene calcrete developed on Lower Jurassic carbonate substrate. A) Polished slab of the Eocene calcrete-sourced gravel derived from the brecciated horizon of a partially or totally eroded calcrete section. Highly irregular to subrounded clasts coated with micritic laminae composed of predominant Pliensbachian limestone fragments. Root-induced brecciation is evidenced by rhizolith (arrow). Coin for scale: $23 \mathrm{~mm}$. B) In situ Microcodium aggregates within root channel. Plane-polarized light. C) Typical Microcodium ("rosette") structure in peloidal calcrete. Plane-polarized light. D) Microcodium aggregate with characteristic opacity of individual grains due to fine inclusions. Plane-polarized light

associated with alveolar texture and Microcodium. In most cases the isodiametric to elongated Microcodium grains with characteristic opaque inclusions and uniform extinction distinctly cluster in aggregates and radiate from central cavities filled with limpid calcite spar cement. The aggregate shape is generally "corn-cob" or cylindrical with rosette appearance in transverse sections, corresponding to the typical Microcodium. In the studied calcrete, peloids and coated grains are also very frequent (Fig. 5). Ooids and pisoids are micritic, rather indistinctly laminated, and have cores of carbonate rock fragments, rarely bioclasts, calcite spar or detrital quartz grains. Additionally, a few coated grains with cores of root-cast fragments, Microcodium grains or intraclasts have been recognized in the calcrete samples, which indicate that the horizon formed through multiple phases of brecciation resulted from penetrative growth of roots and subsequent cementation by micrite (Varga et al. 2002b, 2002c).

The origin of the reworked calcrete clasts is unknown; however, pisolithic and brecciated horizons are common at the top of calcrete profiles where intense brecciation favors the formation of calcrete-sourced clasts (Alonso-Zarza 2003). 

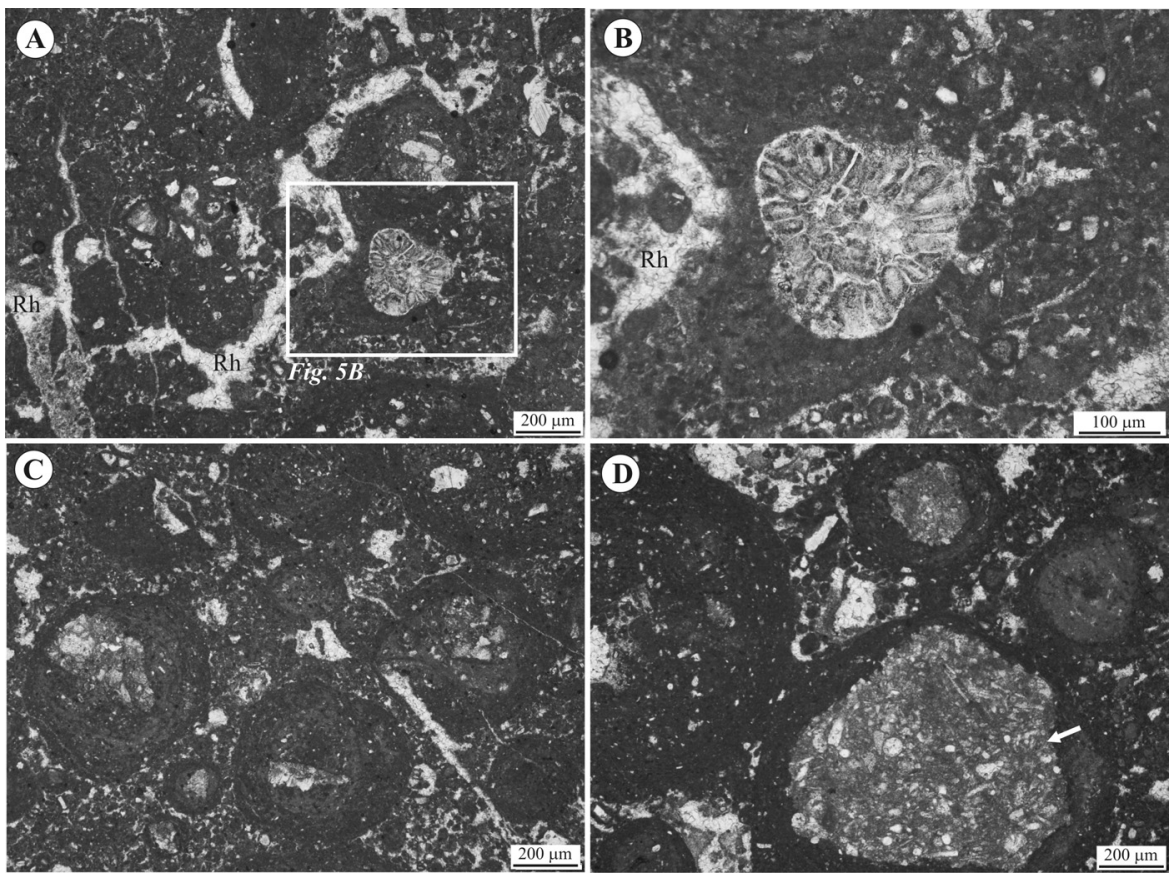

Fig. 5

Eocene calcrete developed on Lower Jurassic carbonate substrate (plane-polarized light). A-B) Spar cement-filled root casts with Microcodium aggregates. C-D) Calcrete peloids (sand-silt-sized micritic grains) and indistinctly laminated, micritic vadose pisoids. Some pisoids have cores of carbonate rock fragments (e.g., bioturbated packstone-wackestone with sponge spiculae and echinoderm fragments; arrow)

Alternatively, Wórum (1999) suggested a Late Oligocene compressional stress field in the studied area, so the occurrence of calcrete-sourced pebbles in the Lower Miocene conglomerate layers may reflect the tectonically-controlled physical erosion of the Szentlőrinc rocks.

\section{Pedogenic calcrete developed on Lower Jurassic (Sinemurian) carbonate substrate}

In a narrow belt between the villages of Ófalu and Zsibrik, southern Transdanubia (Fig. 1B), occurrences of Jurassic rocks are known in an elongated tectonic zone at the southeastern part of the Mecsek Mts (for details see Császár et al. 2007). The relevant part of this Jurassic sequence belongs to the so-called Zobákpuszta Sandstone Formation (formerly a part of Vasas Marl Formation; Raucsik 2012) which is composed of alternating gray sandstone and sandy, calcareous siltstone, claystone and marl beds with gray spherosiderite concretions and Gryphaea coquinas. The formation is of a general fining-upward character and the average carbonate content of the sediments increases upsection, suggest- 

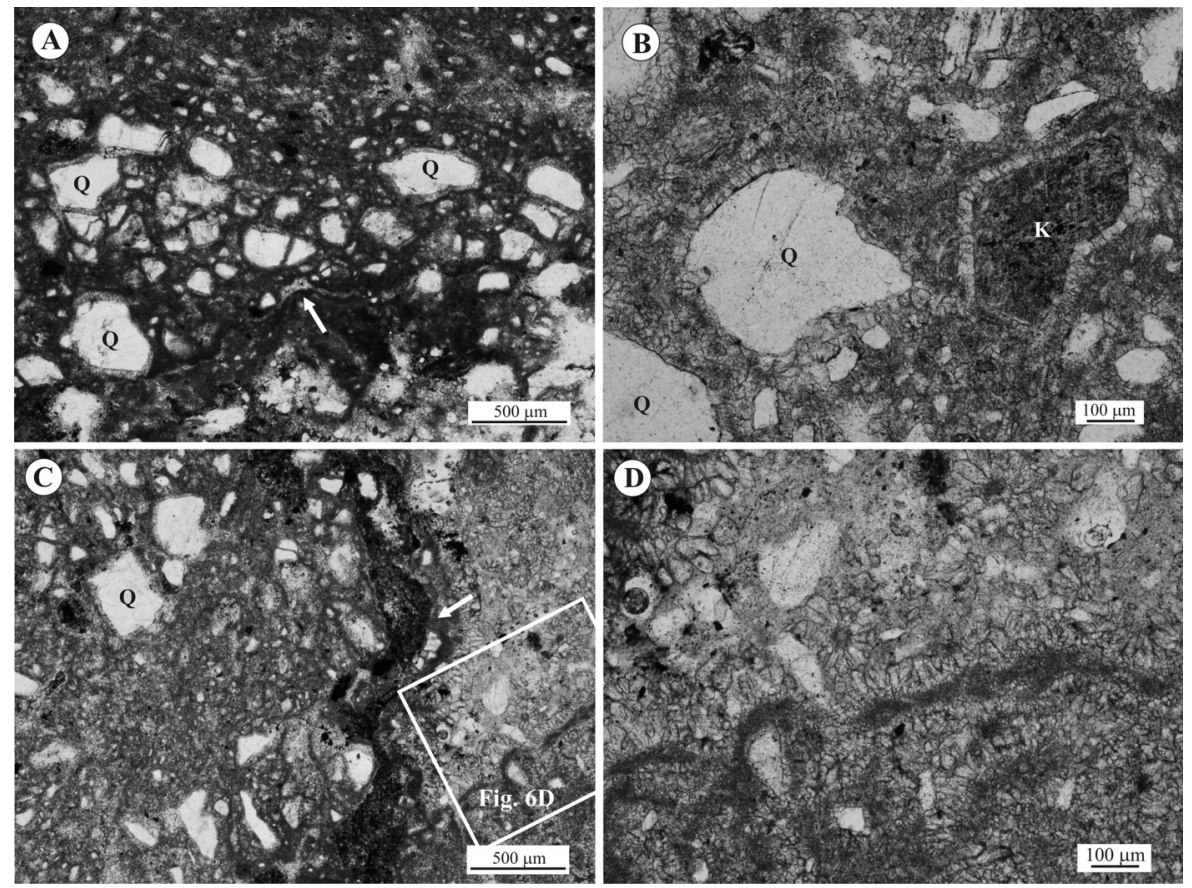

Fig. 6

Photomicrographs of pedogenic calcrete developed on Lower Jurassic (Sinemurian) carbonate substrate (plane-polarized light). A-C) Floating siliciclastic (Q: quartz and K: K-feldspar) grains coated by displacive asymmetric to circumgranular cement rim showing a typical feature of calcretes. The remaining void spaces are filled with micrite or microspar. Root-structures are indicated by arrows. D) Weakly recrystallized Microcodium-like calcite aggregates composed of a single layer of individual, elongate prismatic crystals of calcite

ing transgressive depositional dynamics. Based on its sedimentary structures and fossil assemblage (e.g., bivalves, foraminifers, ostracods, and echinoderm fragments) the formation must have been deposited in the littoral to shallow sublittoral zone of a marine basin with normal salinity during the Sinemurian (Császár et al. 2007).

In the study area, characteristic features of some ancient calcrete formation are restricted to few small outcrops developed over mixed carbonate-siliciclastic sandstone and conglomerate (L4, L12, and L16 outcrops; Császár et al. 2007), showing a weak to moderate degree of actual surface weathering. The altered substrate is characterized by corroded siliciclastic grains (quartz, K-feldspar, and rare muscovite and zircon) with circumgranular calcite rims (Fig. 6) and, sometimes, root structures represented by micrite and/or microspar-filled curved channels, alveolar-septal structures, and probably in-situ corrosive Microcodium. Their aggregates enclose internal areas filled with micrite cement (Fig. 6D). In this area, moderately-preserved Microcodium-like structures of elongate calcite prisms 
(measuring 50-80 $\mu \mathrm{m}$ in length and 10-20 $\mu \mathrm{m}$ in width) have been reported only from outcrop L16 (Varga 2011).

Jurassic rocks here are locally covered by shallow-marine Miocene, Pannonian or Quaternary deposits with unconformities between them (Császár et al. 2007); however, the calcrete formation event has not been dated.

\section{Paleoenvironmental and paleogeographic significance of calcrete records}

Rhizoliths and related features are products of pedodiagenesis; therefore they are indicators of paleosol and hence of subaerial vadose environments in ancient successions (Klappa 1980). During pedogenesis, root respiration produces significant levels of $\mathrm{CO}_{2}$ (and hence of carbonic acid); additionally, microbial decomposition also releases $\mathrm{CO}_{2}$ that controls the dissolution and precipitation of pedogenic carbonate (Wright and Tucker 1991; Alonso-Zarza 2003; Brasier 2011). All workers studying Microcodium in relation to the environment of its formation agree on its biogenic, subsurface, non-marine nature (e.g., Klappa 1978; Kabanov et al. 2008). Two peaks in Microcodium abundance occur at the Moscovian-Early Permian and latest Cretaceous-Paleogene intervals, which are distinct by low $\mathrm{pCO}_{2}$ in the atmosphere (Berner 2006; Royer 2006; Kabanov et al. 2008). Most of the accumulations of Microcodium occur within continental depositional settings that are affected by pedogenesis and/or calcrete formation within palustrine, fluvial, and, rarely, karstic settings. Furthermore, in-situ occurrence of Microcodium aggregates in shallow marine facies always indicates subaerial exposure and pedogenic modification of the sediment (Košir 2004). On the other hand, calcretes as indicators of unconformities could be used in subsurface stratigraphy, providing one more element of basin architecture analysis in buried deposits (Alonso-Zarza and Wright 2010).

With respect to the Lower Permian (Cisuralian) nodular calcrete belonging to the Korpád Formation, the micromorphological features mentioned above, together with the mineralogy suggest a relatively dry climate with low amount of rainfall (100-500 mm/year) during pedogenesis (Varga et al. 2012). This result supports the idea that the southern Transdanubian part of the Tisia Block was located in the arid paleoclimatic belt during the Early Permian. Interestingly, however, no other calcrete record has ever been documented in the Cisuralian continental sequences of the Tisia (see Vozárová et al. 2009, 2010, and references therein). Permian deposits from the Apuseni Mountains (Romania) developed also in continental facies with molassic characteristics where red beds are dominant (Seghedi et al. 2001) but basal black-colored and bituminous shaly deposits suggest a somewhat more humid climate. On the other hand, considered within a Circum-Pannonian context, the depositional basin of the Korpád Formation is well correlated with the Permian basins of the Western Carpathians and the Eastern Alps (Alcapa Block). The Cisuralian sediments of the Zemplinicum (the Cejkov and Černochov Formations) were deposited in an alluvial fan setting alter- 
nating with floodplain or ephemeral lake deposits with calcrete horizons, all showing the typical features of semiarid/arid climatic conditions (Vozárová et al. 2009, 2010). Additionally, calcrete horizons together with lenses of dolomite and gypsum occur locally in the Hronicum Cisuralian sequence (the Malužiná Formation) comprising a thick succession of alternating conglomerate, sandstone and shale deposited in braided alluvial and fluvial-lacustrine environments in a semiarid/arid climate (Vozárová et al. 2009, 2010; Vdačný et al. 2013). Furthermore, in the Drauzug and in the Gurktal Nappe (the Laas Formation and the Werchzirm Formation, respectively), proximal to distal alluvial red-beds, grading into fine-grained sandflat-playa complexes locally with calcrete crust, characterize the Cisuralian (Vozárová et al. 2009, 2010).

In contrast to the Early Permian subaerial exposure section, only sporadic information exists for correlation of younger Transdanubian pedogenic calcretes developed on Lower Jurassic substrates. The aforementioned correlation of the Eocene microflora-bearing calcrete-sourced gravel found in the Lower Miocene Szászvár conglomerate sequence with the Szentlorinc Formation is somewhat speculative, because of insufficient petrographic and biostratigraphic control. Additionally, we are unaware of any Microcodium findings in Paleogene successions from the Hungarian part of the Tisia Block. It is important to note, however, that Microcodium is most extensively reported from the latest Cretaceous-Eocene of the Mediterranean regions (Kabanov et al. 2008, and references therein). Corresponding to the Circum-Pannonian area, excellently documented subaerial exposure surfaces, including calcretes with typical Microcodium, occur within a succession of Upper Paleocene and Lower Eocene shallow-marine limestone (the Trstelj Formation and Alveolina-Nummulites Limestone) in southwestern Slovenia (Košir 2004), so our result fits well with the younger peak of Microcodium abundance in a global context.

Finally, regarding the pedogenic calcrete developed on Lower Jurassic (Sinemurian) carbonate substrate, the calcrete formation event has not been dated. Apart from the aforementioned Eocene unconformity, there are several Neogene and Quaternary subaerial exposure events with calcrete formation in the study area. Calcretes of shallow-marine carbonate systems have been described from the Sarmatian sediments from various parts of Hungary (Fig. 1B). According to Lelkes (1994), sedimentation on a restricted carbonate platform was interrupted by subaerial periods and pedogenesis during the Sarmatian. The diagnostic features for pedogenic calcrete facies identified from 27 core sections are rhizoliths (root molds, root casts, root tubules, rhizocretions, and root petrifactions), alveolar textures, rare typical Microcodium (core Soltvadkert-4 only), calcified insect eggs, peloids, and various types of pedogenic voids (Lelkes 1994). Based on the neighboring location sites (Fig. 1B) the beta calcrete developed on a Lower Jurassic carbonate substrate could probably have formed during the Sarmatian subaerial exposure event. Nevertheless, other cycles separated by unconformities reflecting subaerial vadose environments have also been mentioned in the Neo- 
gene to Quaternary basin fill (e.g., Bajnóczi et al. 2006) so the time of the calcrete formation developed on the Sinemurian substrate and, therefore, its paleoenvironmental relationship cannot be estimated in a satisfactory manner.

\section{Concluding remarks}

This paper summarizes Hungarian examples of calcified plant roots and Microcodium from subaerial exposure sections in southern Transdanubia (Tisia Block), which are characterized by root-influenced fabric but differ in form and stage of development. Three occurrences of rhizoliths together with in-situ Microcodium or poorly to moderately-preserved Microcodium-like structures related to calcrete sections have been documented in the studied area. They are as follows: nodular calcrete belonging to the Lower Permian (Cisuralian) Korpád Sandstone Formation (Western Mecsek Mts), Eocene calcrete-sourced clasts developed on Jurassic substrate from the Miocene Szászvár conglomerate sequence (Western Mecsek Mts), and calcrete of uncertain age developed on carbonate-siliciclastic substrate of the Sinemurian Zobákpuszta Sandstone Formation in a narrow belt between the villages of Ófalu and Zsibrik (Eastern Mecsek Mts).

Interestingly, within a Circum-Pannonian context, Permian calcrete-bearing sediments have not been reported from the Apuseni Mountains (Tisia), but the depositional basin of the Korpád Formation can be correlated to the Permian basins of the Western Carpathians (e.g. Zemplinicum and Hronicum) and the Eastern Alps (e.g., Drauzug and Gurktal Nappe) of the Alcapa Block. In contrast to the Cisuralian subaerial exposure profile, only sporadic information exists for correlation of younger Transdanubian calcretes developed on Jurassic substrates. According to our opinion, if calcretes as indicators of unconformities receive more attention in the area of the Tisia Block they may be used more efficiently in surface/subsurface stratigraphy as well as for regional paleoenvironmental and paleogeographic correlations.

\section{Acknowledgements}

The authors thank Andrea Mindszenty, Miklós Kedves, György Lelkes, György Szakmány, and Sándor Józsa for their valuable consultation and significant help. This research has been supported by the Hungarian Scientific Research Fund (OTKA; No. PD 83511) to AV, and it was additionally supported by the 'TÁMOP-4.2.2. A-11/1/ KONV-2012-0047' project (BR) as well as the Bolyai János Research Scholarship of the Hungarian Academy of Sciences (AV).

\section{References}

Alonso-Zarza, A.M. 2003: Palaeoenvironmental significance of palustrine carbonates and calcretes in the geological record. - Earth-Science Reviews, 60, pp. 261-298. 
Alonso-Zarza, A.M., V.P. Wright 2010: Calcretes. - In: Alonso-Zarza, A.M., L.H. Tanner (Eds): Carbonates in Continental Settings: Facies, Environments, and Processes. Developments in Sedimentology, 61, pp. $225-267$.

Alonso-Zarza, A.M., M.E. Sanz, J.P. Calvo, P. Estévez 1998: Calcified root cells in Miocene pedogenic carbonates of the Madrid Basin: Evidence for the origin of Microcodium b. - Sedimentary Geology, 116, pp. 81-97.

Bajnóczi, B., Z. Horváth, A. Demény, A. Mindszenty 2006: Stable isotope geochemistry of calcrete nodules and septarian concretions in a Quaternary 'red-clay' paleovertisol from Hungary. - Isotopes in Environmental and Health Studies, 42(4), pp. 335-350.

Bakacsi, Zs. 1993: Sedimentology of the freshwater limestone complex of Süttő. - M.Sc. Thesis, Manuscript, Eötvös L. University, Budapest, 108 pp.

Bakacsi, Zs., A. Mindszenty, E. Hertelendi 1994: Lacustrine/palustrine facies from the Pleistocene carbonate lake of Süttő (Hungary). - IAS $15^{\text {th }}$ Regional Meeting, Ischia, Italy, 13-15 April 1994, Abstract Volume, pp. $41-42$.

Barabás, A., Á. Barabásné Stuhl 1998: A Mecsek és környéke perm képződményeinek rétegtana (Stratigraphy of the Permian formations in the Mecsek Mountains and its surroundings). - In: Bérczi, I., Á. Jámbor (Eds): Magyarország geológiai képződményeinek rétegtana (Stratigraphy of formations of Hungary). MOL Rt. and Hung. Geol. Inst. publ., Budapest, pp. 187-215.

Berner, R.A. 2006: GEOCARBSULF: A combined model for Phanerozoic atmospheric $\mathrm{O}_{2}$ and $\mathrm{CO}_{2}$.Geochimica et Cosmochimica Acta, 70, pp. 5653-5664.

Brasier, A.T. 2011. Searching for travertines, calcretes and speleothems in deep time: Processes, appearances, predictions and the impact of plants. - Earth-Science Reviews, 104, pp. 213-239.

Császár G., Á. Görög, Gy. Gyuricza, Á. Sieglné Farkas, I. Szente, B. Szinger 2007: A Vasasi Márga földtani, őslénytani és üledékföldtani jellegei a Zsibrik és Ófalu közötti területen. - Földtani Közlöny, 137(2), pp. $193-226$.

Csontos, L., A. Nagymarosy 1998: The Mid-Hungarian line: A zone of repeated tectonic inversions. Tectonophysics, 297, pp. 51-71.

Csontos, L., A. Nagymarosy, F. Horváth, M. Kovác 1992: Tertiary evolution of the Intra-Carpathian area: A model. - Tectonophysics, 208, pp. 221-241.

Csontos, L., L. Benkovics, F. Bergerat, J. Mansy, G. Wórum 2002: Tertiary deformation history from seismic section study and fault analysis in a former European Tethyan margin (the Mecsek-Villány area, SW Hungary). - Tectonophysics, 357, pp. 81-102.

Esteban, M. 1972: Una nueva forma de prismas de Microcodium elegans Glueck 1912 y su relación con el caliche del Eoceno Inferior, Marmellá, provincia de Tarragona (España). - Instituto de Investigaciones Geologicas, Universidad de Barcelona, Revista 27, pp. 65-81.

Fazekas, V. 1987: Mineralogical composition of Permian and Lower Triassic clastics from the Mecsek Mts. Földtani Közlöny, 117(1), pp. 11-30.

Gierlowski-Kordesch, E., J.C. Gómez Fernández, N. Meléndez 1991: Carbonate and coal deposition in an alluvial-lacustrine setting: Lower Cretaceous (Weald) in the Iberian Range (east-central Spain). - In: Anadón, P., L. Cabrera, K. Kelts (Eds): Lacustrine Facies Analysis. Spec. Publs Int. Ass. Sediment., Blackwell Scientific Publications, Oxford, London, Edinburgh, Boston, Melbourne, Paris, Berlin, Vienna, pp. 109-125.

Glück, H., 1912: Eine neue gesteinbildende Siphonee (Codiacee) aus dem marinen Tertiär von Südeutschland. - Mitt. Bad. Geol. Landesanst., 7, pp. 3-21.

Jámbor, Á. 1964: A Mecsek hegység alsóperm képződményei (Lower Permian formations of the Mecsek Mountains). - Unpublished report, MÉV Adattár (J-0074), Budapest, 113 pp.

Kabanov, P., P. Anadón, W.E. Krumbein 2008: Microcodium: An extensive review and a proposed non-rhizogenic biologically induced origin for its formation. - Sedimentary Geology, 205, pp. 79-99.

Klappa, C.F. 1978: Biolithogenesis of Microcodium: Elucidation. - Sedimentology, 25, pp. 489-522.

Klappa, C.F. 1980: Rhizoliths in terrestrial carbonates: Classification, recognition, genesis and significance. Sedimentology, 27, pp. 613-629.

Konrád, Gy., K. Sebe 2010: Fiatal tektonikai jelenségek új észlelései a Nyugat-Mecsekben és környezetében. - Földtani Közlöny, 140(2), pp. 135-162. 
Košir, A. 2004: Microcodium revisited: Root calcification products of terrestrial plants on carbonate-rich substrates. - J. Sed. Res. 74(6), pp. 845-857.

Lelkes, Gy. 1994: Vadose diagenetic carbonates (Caliches) in the Sarmatian (Miocene) of Hungary. - In: Jubilee Volume of 20 year-old Austrian-Hungarian Co-operation in Geology, 2, pp. 89-104.

Mindszenty, A., F.J. Deák 1999: Karbonátos paleotalajok a gerecsei felső-triászban. - Földtani Közlöny, 129(2), pp. 213-247.

Raucsik, B. 2012: Zobákpusztai Homokkő Formáció (Zobákpuszta Sandstone Formation). - In: Főzy, I. (Ed.): Magyarország litosztratigráfiai alapegységei - Jura (Basic lithostratigraphic units of Hungary - Jurassic). Magyarhoni Földtani Társulat, Budapest, pp. 149-151.

Royer, D.L. 2006: $\mathrm{CO}_{2}$-forced climate thresholds during the Phanerozoic. - Geochimica et Cosmochimica Acta, 70, pp. 5665-5675.

Seghedi, A., M. Popa, G. Oaie, I. Nicolae 2001: The Permian system in Romania. - Natura Bresciana, Ann. Mus. Civ. Sc. Nat., Brescia, Monografia N. 25, pp. 281-293.

Varga, A. 2000: Újabb adatok a mecseki paleogén képződmények ismeretéhez: eocén karbonátos paleotalaj kavicsok a nyugat-mecseki miocén konglomerátumból (Eocene calcrete gravels of the Miocene conglomerate from the western Mecsek Mountains). - Thesis of the National Scientific Conference of Students, ELTE Dept. of Petrology and Geochemistry, Budapest, 45 pp.

Varga, A.R. 2002: A dél-dunántúli eocén (paleogén) képződmények kőzettani vizsgálata és lehordási területének meghatározása (Petrography and provenance of the Eocene [Paleogene] sedimentary rocks from Southern Transdanubia, Hungary). - Thesis of the National Scientific Conference of Students, ELTE Dept. of Petrology and Geochemistry, Budapest, 69 pp.

Varga, A. 2009: A dél-dunántúli paleozoos-alsó-triász sziliciklasztos kőzetek kőzettani és geokémiai vizsgálatának eredményei (Petrology and geochemistry of the Paleozoic-Lower Triassic siliciclastic rocks from Southern Transdanubia, Hungary). - PhD dissertation, ELTE Dept. of Petrology and Geochemistry, Budapest, $150 \mathrm{pp}$.

Varga, A. 2011: Bizonytalan korú paleotalajra (kalkrít) utaló mikromorfológiai bélyegek a Vasasi Márga Formáció kőzeteiben (Zsibrik és Ófalu közötti terület, Mecsek) (Micromorphology of the pedogenic calcrete of uncertain age developed on carbonate-siliciclastic substrate of the Vasas Marl Formation [between the villages of Ófalu and Zsibrik, Mecsek Mts]. - Földtani Közlöny, 141(1), pp. 89-92.

Varga, A., B. Raucsik, B. Wéber, Gy. Szakmány 2002a: Calcrete- and brown coal-bearing Eocene fluvial sequence from Southern Transdanubia - A unique continental basin from S Hungary. - Geologica Carpathica, 53, special issue, Proceedings of the XVII. Congress of Carpathian-Balkan Geological Association, Bratislava, September 1-4, 2002, electronical form, 4 pp.

Varga, A., Gy. Szakmány, B. Raucsik 2002b: Micromorphology and mineralogy of the Eocene calcrete gravel from the Mecsek Mountains (S Hungary). - Acta Geologica Hungarica, 45(3), pp. 287-299.

Varga, A., Gy. Szakmány, B. Raucsik, M. Kedves, S. Józsa 2002c: Eocén calcrete kavicsok a nyugat-mecseki miocén konglomerátumból. - Földtani Közlöny, 132(1), pp. 57-82.

Varga, A.R., B. Raucsik, M. Kedves 2004: A dél-dunántúli eocén (paleogén) képződmények lehordási területének meghatározása - I. Ásványtani, kőzettani és palinológiai vizsgálati eredmények (Provenance of Eocene [Paleogene] siliciclastic rocks from Southern Transdanubia [Tisza Megaunit, Hungary]. Part one: Mineralogical, petrological and palynological results). - Földtani Közlöny, 134(2), pp. 175-200.

Varga, A., B. Raucsik, B. Bajnóczi 2012: Nodular calcrete from the Lower Permian Korpád Sandstone Formation (borehole Dinnyeberki 9015, Mecsek Mts, Hungary) and its palaeoenvironmental significance. Földtani Közlöny, 142(4), pp. 445-468.

Vdačný, M., A. Vozárová, J. Vozár 2013: Geochemistry of the Permian sandstones from the Malužiná Formation in the Malé Karpaty Mts (Hronic Unit, Western Carpathians, Slovakia): Implications for source-area weathering, provenance and tectonic setting. - Geologica Carpathica 64(1), pp. 23-38.

Vozárová, A., F. Ebner, S. Kovács, H-G. Kräutner, T. Szederkényi, B. Krstić, J. Sremac, D. Aljinovič, M. Novak, D. Skaberne 2009: Late Variscan (Carboniferous to Permian) Environments in the Circum Pannonian Region. - Geologica Carpathica, 60(1), pp. 71-104.

Vozárová, A., F. Ebner, S. Kovács, H-G. Kräutner, T. Szederkényi, B. Krstić, J. Sremac, D. Aljinovič, M. Novak, D. Skaberne 2010: Late Variscan (Carboniferous to Permian) environments in the Circum-Pannonian Region. - In: Vozar, J. (Ed.): Variscan and Alpine Terranes of the Circum-Pannonian Region. Slovak Academy of Sciences, Geological Institute, Bratislava, pp. 51-86. 
Wéber, B. 1982: A Mecsekalja árok neogén és paleogén képződményeiről (On the Neogene and Paleogene of the Mecsekalja graben (S Hungary)). Földtani Közlöny, 112, pp. 209-240.

Wéber, B. 1985: Paleogén rétegek Szigetvár környékén (Paleogene beds in the vicinity of Szigetvár (S Hungary). - Földtani Közlöny, 115(1-2), pp. 1-21.

Wórum, G. 1999: A mecsek-villányi térség szerkezete és fejlődéstörténeti eseményei szeizmikus szelvények alapján (Structure and evolution of the Mecsek-Villány area - Interpretation of seismic profiles). Manuscript, ELTE Geofizikai Tanszék és Általános- és Történeti Földtan Tanszék, Budapest, 135 pp.

Wright, V.P. 1990: A micromorphological classification of fossil and recent calcic and petrocalcic microstructures. - In: Douglas, L.A. (Ed.): Soil Micromorphology: A Basic and Applied Science. Developments in Soil Science, 19, pp. 401-407.

Wright, V.P., M.E. Tucker 1991: Calcretes: An Introduction. - In: Wright, V.P., M.E. Tucker (Eds):

Calcretes. Blackwell Scientific Publications, Reprint Series of the IAS, 2, pp. 1-22. 